Article

\title{
Urban Coastal Flood-Prone Mapping under the Combined Impact of Tidal Wave and Heavy Rainfall: A Proposal to the Existing National Standard
}

\author{
Dewayany Sutrisno *(i), Ati Rahadiati $\odot$, Aninda W. Rudiastuti, Ratna Sari Dewi $\odot$ and \\ Munawaroh $(\mathbb{D}$ \\ Center for Research, Promotion and Cooperation, Geospatial Information Agency, Jalan Raya Jakarta Bogor Km \\ 46, Cibinong 16911, Indonesia; ati.rahadiati@big.go.id (A.R.); aninda.wisaksanti@big.go.id (A.W.R.); \\ ratna.sari@big.go.id (R.S.D.); munawaroh@big.go.id (M.) \\ * Correspondence: dewayany@big.go.id; Tel.: +62-21-8790-6041
}

Received: 24 July 2020; Accepted: 27 August 2020; Published: 1 September 2020

\begin{abstract}
The drivers for coastal flooding may vary from extremely high intensity and persistent rainfall, morphological factors of the coastal area, to extreme waves from the ocean. This means that the flood vulnerability of a coastal area does not solely depend on a single driver but can be a combination with others. A national standard for coastal flooding based on rainfall drivers has been developed. As an evaluation, this study aimed to develop a method for coastal flood-prone mapping by combining rainfall with tidal waves. The steps included the assessment of the coastal flood-prone areas driven by rainfall (CFR) and the coastal flood-prone areas by combined drivers (CFC), which was developed by employing the analytic hierarchy process (AHP), spatial-overlaid, weighted-scored, and logical tests. The coastal area of Mataram City on the Island of Lombok in Indonesia was selected as the study area, since it is frequently affected by flooding. The findings determined the essentiality of the CFC method for identifying flood vulnerability areas. Thus, the minimum standard for CFC parameters can be defined with climatic and land characteristic factors. Further, the findings also identified the need for expert judgment in the development of the CFC weighted score-based method.
\end{abstract}

Keywords: coastal flood; tidal wave; rainfall

\section{Introduction}

One of the impacts of climate change is that extreme currents and tidal wave activity has increased flooding rates in coastal and riverine flood plains $[1,2]$. The intensity of flooding events will extend the degradation of coastal habitats and the devastation of coastal settlements. The occurrence of flooding may be caused by the combination of natural and anthropogenic factors. Natural factors include extremely high intensity and persistent rainfall, morphological factors of the coastal area, and extreme waves from the ocean. Meanwhile, anthropogenic factors could be related to human behaviors in utilizing the coastal environment, such as the conversion of the coastal ecosystem to the unsustainable development of residential areas, tourism, industries, ports, and other exploitations [3].

Coastal flooding usually occurs in low-lying areas, which are flooded by seawater [4]. According to [4], the extent of coastal flooding is a result of the penetration of inland floodwaters controlled by the topography of the coastal land exposed to the flooding. Within coastal areas, flooding can occur not only from overflowing streams caused by heavy rainfall but, also, by inflowing water from the ocean. There are various kinds of flooding, such as tidal flooding, which typically occurs during extremely high tides [5]. Other types of floods can be caused by heavy rains, storm surges, and high waves that arise during coastal storms [6]. The tidal flood in the coastal area of the city of Semarang, Indonesia 
that led to a coastal recession is one example of the extreme impact of coastal flooding [7,8]. Another example was the West Cliff Drive area in Santa Cruz, CA, USA, which has been moved landward at about $0.5 \mathrm{~m} /$ year due to the tidal wave activities [9].

Coastal flooding is a global issue that has caused the degradation of the coastal environment and affected the lives of 20 to 200 people who were exposed to flooding [10]. Therefore, the study of coastal flooding and mapping methodology needs to be evaluated. Flooding has occurred frequently in Indonesia; over the past century, 108 times were recorded, accounting for 33.3\% of all disaster events [11]. As a consequence, the mapping of flood-prone areas needs to be regularly updated, so that proper planning can be done regarding the inshore urban areas in Indonesia. Flood-prone area mapping within a coastal area should adequately refer to existing standards to support the development of precise, accurate, and standardized spatial information. A national standard, SNI 8197:2015, concerning the mapping method for flood-prone measures at 1:50,000 and 1:25,000 scales with the primary issues of rainfall and overflowing streams have been published and nationally implemented [12]. However, the implementation of the standard is not mandatory. Consequently, the method of flood-prone mapping may vary among scientists, potentially generating different results that may lead to inaccuracy. For example, the standard and [11] used three parameters of flooding-prone criteria: rainfall, slope, and land use. Despite using the same parameters, the methods applied were dissimilar. Ref. [11] used a pairwise comparison approach to specify the weight of each parameter, while the national standard document set the weighted value into $30 \%$ and $70 \%$ for the rainfall and slope parameters, respectively. Ref. [11] only considered rainfall as the driver of flooding and ignored the existence of ocean drivers such as tidal waves that have been studied and implemented internationally by $[1,2,13]$. This is not in-line with The General Guidelines for Disaster Risk Assessment that states the importance of wave height, current vegetation cover, coastline shape, and coastal typology for determining a flood-prone assessment [14]. Ref. [15] also states the need for an urban-flooding assessment by considering multiple process drivers. Therefore, the objective of this study is to develop a method for coastal flood-prone mapping by combining the rainfall and tidal waves as the drivers and the land characteristics of the coastal area. Before the development of the combined method, an evaluation of the coastal flooding method caused by heavy rainfall was assessed to develop a better equation as an update to the existing flood-prone mapping method.

\section{Study Area}

The coastal area of Mataram City, on the Island of Lombok, Indonesia, was selected as the study area (Figure 1). Located at $8^{\circ} 33^{\prime}-8^{\circ} 38^{\prime} \mathrm{S}$ and $116^{\circ} 04^{\prime}-116^{\circ} 10^{\prime} \mathrm{E}$, Mataram City directly faces the Lombok Strait, which separates Lombok Island with the Island of Bali. The Lombok Strait is designated as a channel for the implementation of the right of Archipelagic Sea lane passage based on international maritime law conventions, which connects the Pacific Ocean in the north with the Indian Ocean in the south. The Lombok Strait has a vital role controlling the dynamics of the movement of water masses from the Pacific Ocean to the Indian Ocean [16], which can have an impact on tidal waves on the coast of the city of Mataram.

Lombok Island is also famous as a tourist destination as Bali, but the island is vulnerable to floods, earthquakes, tsunamis, droughts, extreme waves, abrasion, and extreme weather [17]. Based on the land system map of Mataram from Badan Informasi Geospasial, the coastal geomorphological type of the study area is an alluvial plain, with flat topography and sandy clay soil. The two rivers that have the impact of flooding emptying into the coast of Mataram are the Jangkik River and the Unus River. Mataram City is inundated every year, and the impact is exacerbated during monsoons [18]. Tidal waves are the major factor that caused inundation in the coastal city of Mataram [19-21]. A major flood occurred in January 2017 where tidal waves inundated 1161 houses on the coast of Mataram [18]. Research by [18] has projected that, within the next 50 years, the coast of Mataram City will likely be inundated without any mitigating actions. 


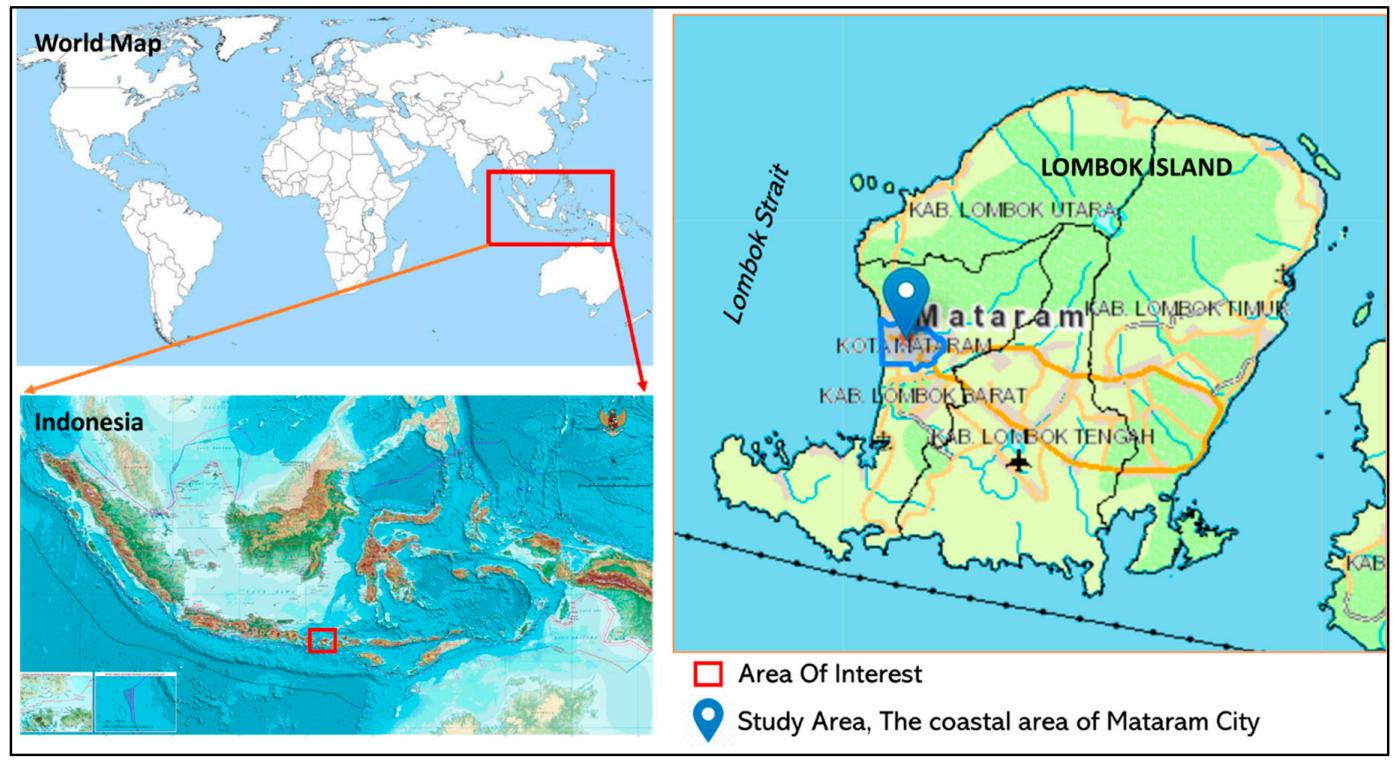

Figure 1. A map of the study site (source: [22,23]).

\section{Materials and Methods}

This study assessed two methods of flood-prone mapping: coastal flood-prone areas driven by rainfall (CFR) and coastal flood-prone areas by combined drivers (CFC). The latter method combined a series of coastal flood-prone methods in the existing national standard while adding tidal waves as a driver from the ocean. The development of both methods employed multi-analysis criteria, including pairwise comparison using the analytic hierarchy process (AHP) method, overlay method, weighted-scored method, and logical tests to validate the results.

The data for the study consisted of:

(a) Tidal data obtained from the website of Tide Observation and Prediction-Geospatial Information Agency (we referred to BIG: "Badan Informasi Geospasial" in Indonesian) (http://tides.big.go.id). The average of highest tidal data was assessed after data acquisition.

(b) The rainfall data obtained from the website of the Tropical Rainfall Measuring Mission/TRMM (https://trmm.gsfc.nasa.gov) The National Aeronautics and Space Administration (NASA), USA. The maximum average of 10 years of rainfall data was assessed.

(c) The land-use/land cover data obtained from the BIG digital Rupabumi map (base map) of Mataram City at a 1:5000 scale.

(d) The slope data obtained from the BIG seamless digital elevation model (DEM) and National Bathymetry website (https://tides.big.go.id/DEMNAS). The digital terrain model (DTM) data were obtained within a 0.27 -arc-second spatial resolution and converted into a slope by using the 3D analyst of GIS software.

(e) The geomorphological data extracted and assessed from the digital land system map of Mataram City, published by BIG at a 1:25,000 scale and the digital soil map from the Indonesian Center for Agriculture Land Resources Research and Development at a 1:50,000 scale, Bogor- Indonesia.

The coastal alluvial plain was used as the object of the mapping to examine the extent of flooding, as morphological descriptors are good indicators of flood hazard exposure [24-26]. In this case, the alluvial plain of the Mataram Coast is a critical geomorphological unit due to its vulnerability to flooding.

The workflow of this research is summarized in Figure 2. 


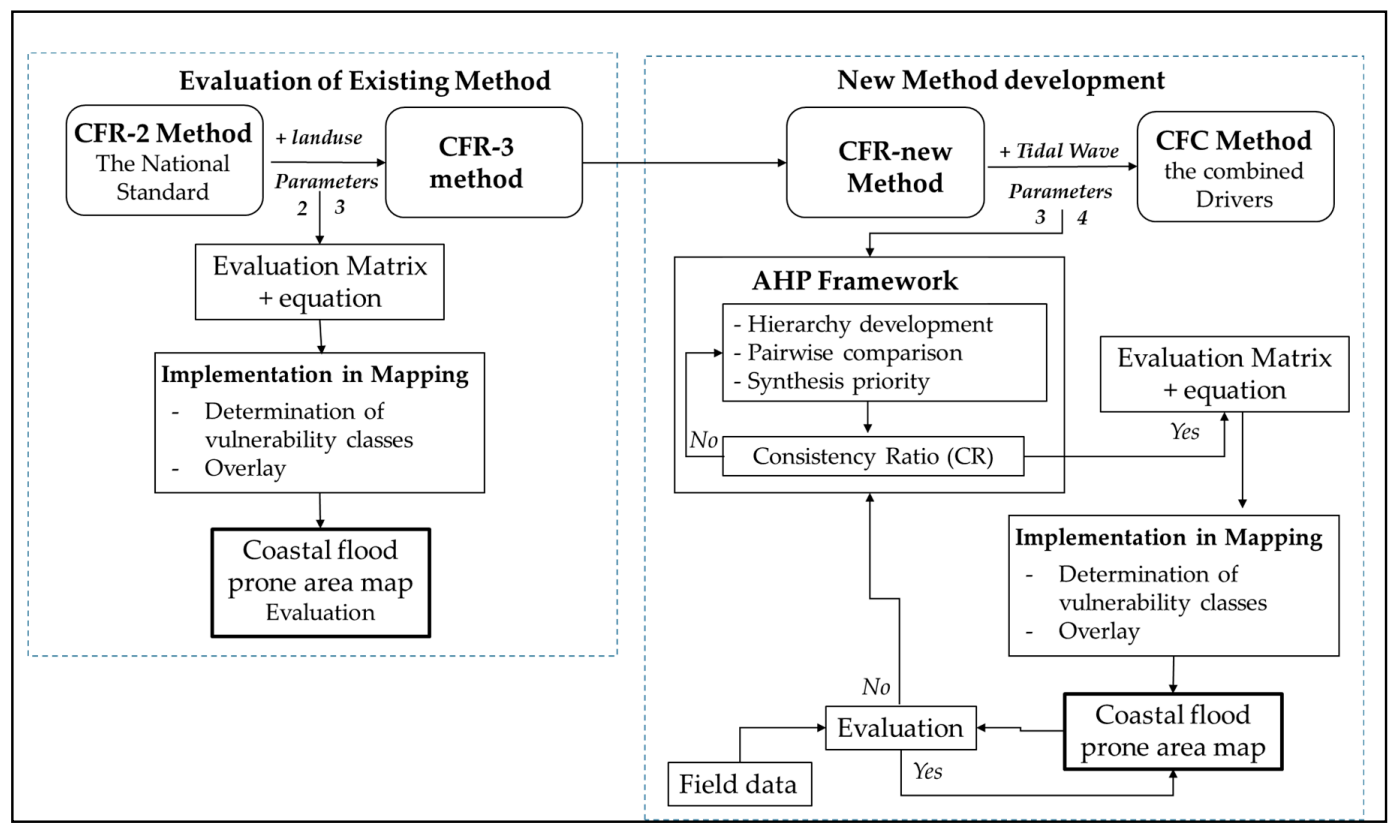

Figure 2. Workflow scheme of the study. CFR: coastal flood-prone areas driven by rainfall.

The stages are explained as follows:

\subsection{Evaluation of the Existing Method}

Prior to the assessment of the $\mathrm{CFC}$, this study needed to examine the existing national standard (CFR-2) as the basis of the combined driver model (CFC). Previously, the national standard [12] used rainfall to represent the climate and slope to represent the land characteristics but assumed the land cover parameter along the coastal city was homogeneous. However, [27-30] highlighted the importance of urban sprawls as an increasing driver of urban flood risk and indicated the relevance of land use for assessing the potential of flood hazard impacts in coastal areas. Ref. [31] supported the role of land cover/use for a flooding assessment in Mataram City, because $8.59 \%$ of the coastal built-up area was a conversion from agricultural land (rice fields). Besides, [32] stated that inundation adaptation should become a land-use issue rather than an engineering perspective. Therefore, the importance of the land-use cover parameter cannot be discounted. CFR-2 was modified to CFR-3 by adding the land cover/use parameter (see the matrix of multi-criteria evaluation (MCE) in Table 1) 
Table 1. Shows the matrix of MCE for coastal flood-prone areas driven by rainfall (CFR)-2 and CFR-3 based on [12].

\begin{tabular}{|c|c|c|c|c|c|c|c|c|c|c|c|c|c|c|}
\hline \multirow{2}{*}{\multicolumn{2}{|c|}{ Parameter $w$}} & \multicolumn{6}{|c|}{ CFR-2 Classes } & \multirow{2}{*}{$w$} & \multicolumn{6}{|c|}{ CFR-3 Classes } \\
\hline & & High & $S$ & Moderate & $S$ & Low & $S$ & & High & $s$ & Moderate & $s$ & Low & $S$ \\
\hline Slope & 70 & $0-2 \%$ & 3 & $2-4 \%$ & 2 & $>4 \%$ & 1 & 35 & $0-2 \%$ & 3 & $2-4 \%$ & 2 & $>4 \%$ & 1 \\
\hline $\begin{array}{l}\text { Land } \\
\text { cover/use }\end{array}$ & & & & & & & & 35 & Settlements & 3 & $\begin{array}{l}\text { Bushes/ } \\
\text { agriculture/ } \\
\text { mixed } \\
\text { crops/ } \\
\text { plantations }\end{array}$ & 2 & $\begin{array}{l}\text { Rice } \\
\text { fields/ } \\
\text { forest/ } \\
\text { gardens/ } \\
\text { sand/ } \\
\text { bare } \\
\text { land }\end{array}$ & \\
\hline Rainfall & 30 & $\begin{array}{l}\geq 200 \\
\mathrm{~mm}\end{array}$ & 3 & $\begin{array}{l}50-200 \\
\mathrm{~mm}\end{array}$ & 2 & $\begin{array}{l}\leq 50 \\
\mathrm{~mm}\end{array}$ & 1 & 30 & $\begin{array}{l}\geq 200 \\
\mathrm{~mm}\end{array}$ & 3 & $\begin{array}{c}50-200 \\
\mathrm{~mm}\end{array}$ & 2 & $\begin{array}{l}\leq 50 \\
\mathrm{~mm}\end{array}$ & 1 \\
\hline
\end{tabular}

The equation of the matrix is described as follows:

$$
F_{i}=\sum w_{i} s_{i}
$$

where $F_{i}$ is the flood-prone area of class $i, w_{i}$ is the weighting for the flood-prone area of class $i$, and $s_{i}$ is the scoring for the flood-prone area of class $i$.

\subsection{New Method Development}

\subsubsection{CFR-New method}

A spatial analysis that employs the weighted-score method has a critical issue in the weighting variable, because the values are utilized to calculate the level of priority of an analysis involving multiple attributes [33-35]. Thus, to assess the object classification based on the weighted score method, it is essential to learn the weighting factors, especially when multiple features are used to distinguish variable object classes. The AHP method was used to specify the weight of the three parameters in the flood-prone area criteria (CFR-3) to develop the new CFR method. Firstly, the Saaty method, as quoted in [36], was used to identify the hierarchy structure of used parameters with a scale of 1 to 9. Secondly, a pairwise comparison matrix was developed and normalized to synthesize the priority level by calculating the eigenvector to obtain the weight values of the used criteria. The equations of the methods can be expressed as follows

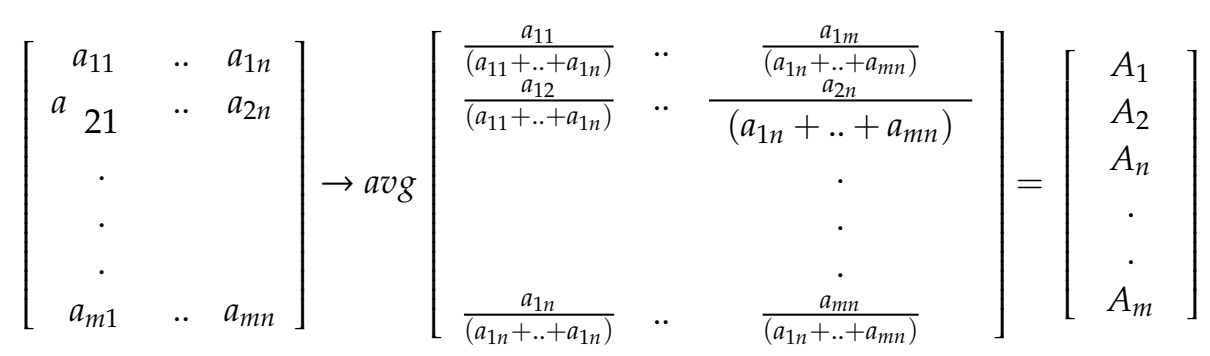

where $A_{1 \text { to } n}$ is the average of $\left(\frac{a_{11}}{\left(a_{11}+. .+a_{1 n}\right)} \ldots \frac{a_{1 n}}{\left(a_{1 n}+. .+a_{m n}\right)}\right)$ as the eigenvectors; $a_{11}$ to $a_{m n}$ is the value of the performance rating towards the parameters.

Then, the weighted decision was calculated based on the normalized matrix and eigenvectors as follows:

$$
w_{1}^{n}=\left(\frac{a_{11}}{\left(a_{11}+. .+a_{1 n}\right)}\right) *\left(\frac{a_{1 n}}{\left(a_{1 n}+. .+a_{m n}\right)}\right) * A_{1}^{n}
$$

where $w$ is the weighted value of parameters 1 to $n$. 
Thirdly, the consistency of the weighting value assessment-Saaty's consistency ratio (CR), as quoted in [37] —-was assessed. The $C R$ is a comparison of the consistency index (CI) with a random index $(R I)$ value, as follows:

$$
C R=\frac{C I}{R I}
$$

where $C I$ is determined by $\lambda_{\max }$ (the largest eigenvalue) and the number of parameters, $n$,

$$
C I=\frac{\lambda_{\max -1}}{n-1}
$$

If a pairwise comparison matrix has a $C R \leq 0.100$, then the inconsistency in the decision-makers' opinions is still acceptable; otherwise, the assessment needs to be repeated.

If $\mathrm{CR} \leq 0.100$, then the spatial analysis will be employed by using the following equations:

$$
F_{i}=w_{1} s_{i p 1}+w_{2} s_{i p 2}+\cdots+w_{3} s_{i p n}
$$

where $F_{i}$ is the flood-prone area of class $i, w_{1 . . n}$ are the weighting factors for the parameters $p_{1}$ to $p_{n}$, and $S_{i}$ is the scoring value for the flood-prone area class $i$ for the parameters $p_{1}$ to $p_{n}$.

\subsubsection{CFC Method Development}

The most crucial issues of this study were to develop the method of CFC mapping and to assess how much the potential impact is of tidal waves on coastal flooding. The AHP method was also used to specify the weights of the parameters, assessed according to Equations (2)-(6).

An important thing that needed to be considered in the development of the CFC was the extent to which a tidal wave would inundate the coastal area. The spatial analysis for the tidal wave over wash or landward inundation $\left(x_{r}\right)$ can be defined as a function of the height of the tidal wave $\left(h_{c}\right)$, the depth at the still-water line $\left(h_{o}\right)$, and the difference between the still-water level and the normal tide $\left(x_{p}\right)$, while $\theta$ is the angle between the water level when tidal wave landward inundation occurs with the beach slope (see Figure 3). Next, the CFC method can be determined following Equation (7).

$$
x_{r}=\frac{\left(h_{c}+h_{0}\right)}{\tan \theta}-x_{p}
$$

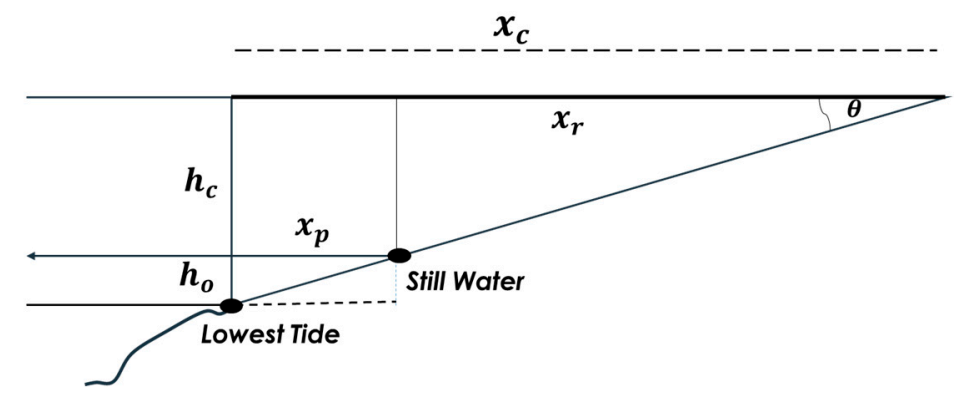

Figure 3. Scheme illustration of the tidal wave landward inundation.

\subsubsection{Implementation of the Methods in Mapping}

Equation (6) was used to determine the interval of the vulnerability classes, which can be explained in Table 2. 
Table 2. The estimation of the vulnerability classes.

\begin{tabular}{cccc}
\hline \multicolumn{2}{c}{ Flood-Prone Area } & Class Interval & $\begin{array}{c}\text { Vulnerability } \\
\text { Classes }\end{array}$ \\
\cline { 1 - 2 } Flood-Prone Classes & $\boldsymbol{F}_{\boldsymbol{i}}=\boldsymbol{w}_{1} \boldsymbol{s}_{\boldsymbol{i p} 1}+\cdots+w_{m} \boldsymbol{s}_{\text {ipn }}$ & & \\
\hline$F_{\text {high }}$ & $w_{1} * S_{\text {high } 1}+\cdots+w_{m} * S_{\text {highpn }}=\mathrm{Z}$ & $>\mathrm{Y}-\mathrm{Z}$ & $C_{\text {high }}$ \\
$F_{\text {_mod }}$ & $w_{1} * S_{\text {modp } 1}+\cdots+w_{m} * S_{\text {modpn }}=\mathrm{Y}$ & $>\mathrm{X}-\mathrm{Y}$ & $C_{\text {_mod }}$ \\
$F_{\text {_low }}$ & $w_{1} * S_{\text {lowp } 1}+\cdots+w_{m} * S_{\text {lowp }}=\mathrm{X}$ & $0-\mathrm{X}$ & $C_{\text {_low }}$ \\
\hline
\end{tabular}

Notes: $C_{\text {low }}=$ low vulnerability, $C_{\text {mod }}=$ moderate vulnerability, and $C_{\text {high }}=$ high vulnerability.

Afterward, the map of the coastal flood-prone area for CRF-2, CFR-3, CFR-new, and CFC were developed by using the overlay analysis using GIS software.

\subsubsection{Field data inventory}

The field data inventory was carried out as a reference to evaluate the results of the study due to the unavailability of a recent detailed flood disaster map for the study area. The field data consisted of interview data from local people in the identified flood-prone areas and the point data of the flood locations. The respondents for the in-depth interviews were randomly selected from four clusters of flood-prone areas, which were identified based on the coastal village administration, as suggested by The Regional Board for The Disaster Management Office. Three respondents were selected from each cluster, followed by a field-mapping of the flood-prone area and the tracking of the flood-prone boundaries. The contents of the interview dealt with the discussion of flooding events and at least consisted of when, where, how long, how significant the flooding, the frequency of flooding/how often per year, when was the worst flooding, how much it has affected the people's lives, and how is the emergency response and mitigation works.

\subsubsection{Evaluation}

The evaluation was carried out by assessing the findings with the data obtained from the field survey using the logical test method. Both the references and the study derived map were analyzed according to the arranged matrix; then, the test was carried out following the method described by [38] as follows:

$$
\begin{aligned}
& \text { if }(x, y)_{1}=(x, y)_{n} \text {, then }(x, y)_{1} \text { is true } \\
& \text { if }(x, y)_{1} \neq(x, y)_{n} \text {, then }(x, y)_{1} \text { is false }
\end{aligned}
$$

where $(x, y)_{n}$ is a reference point data of the flood location.

The total evaluation value $(E v)$ can then be determined as

$$
E v=\frac{\sum t_{1}+t_{n}}{\sum(P)_{r e f}} \times 100 \%
$$

where $E v$ is the result of the evaluation (\%) based on $t=$ a true value and $f=$ a false value, $1 \ldots n$ are the flood-prone points from the study, and $P_{\text {ref }}$ is the field reference data.

The logical test analysis was applied for both the classified CFC map into three vulnerable classes and the not-classified derived map.

\section{Results}

\subsection{Coastal Flood-Prone Area Method Based on Rainfall}

The results that compared the standard with two parameters (CFR-2) and the CFR-3 show that, by adding the land cover parameter to the method, different levels and extents of the potential disaster can 
be identified (see Figure 4). The highly vulnerable area increased with the CFR-3 method (b) compared with the CFR-2 method (a) (Figure 4).

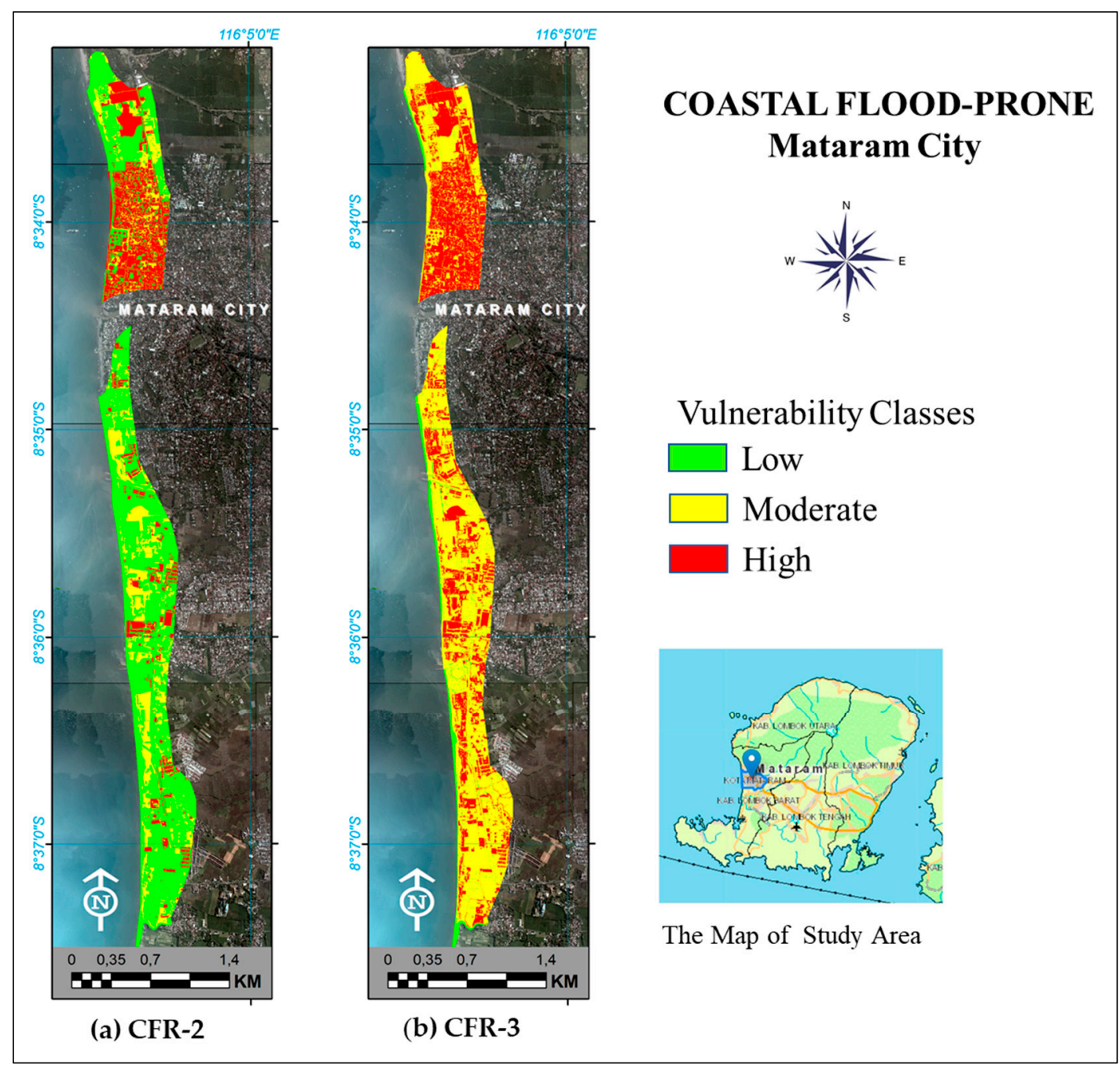

Figure 4. The result of CFR mapping based on CFR-2 (a) and CFR-3 (b).

However, because the consistency of the original weighting remained unclear, we updated the weighting variable and reassessed the CFR-3 to become the CFR-new. The CFR-new method was developed based on an AHP analysis, which used a pairwise comparison matrix to determine the level of importance (priority scale) of the used parameters. A judgment matrix was constructed for CFR-new, as shown in Table 3, which summarizes the normalized weights. The matrix ( $\lambda$ max $=3.0387$; $\mathrm{CI}=0.0194 ; \mathrm{RI}=0.58 ; \mathrm{CR}=0.0334<0.1$ ) passed the consistency evaluation. So, the measured weighting values can be used for the development of the new CFR equations (CFR-new). 
Table 3. Analytic hierarchy process (AHP) judgment matrix of the CFR-new-affecting parameters and consistency ratio assessment.

\begin{tabular}{|c|c|c|c|c|c|c|c|c|c|}
\hline & $\begin{array}{l}\text { Land } \\
\text { Cover/Use }\end{array}$ & Slope & Rainfall & $\sum_{\text {Row }}^{\sum}$ & Eigenvector & Results & Weight & $\begin{array}{l}\text { Weighted } \\
\text { Sum } \\
\text { Vector } \\
\text { (WSV) }\end{array}$ & $\begin{array}{l}\text { Consistency } \\
\text { Vector (CV) }\end{array}$ \\
\hline $\begin{array}{l}\text { Land } \\
\text { cover/use }\end{array}$ & 1 & 3 & 5 & 1.90 & 0.6333 & 1.2033 & 1.20 & 1.9458 & 3.0725 \\
\hline Slope & 0.33 & 1 & 3 & 0.78 & 0.2605 & 0.2032 & 0.20 & 0.7902 & 3.0334 \\
\hline Rainfall & 0.20 & 0.33 & 1 & 0.32 & \multicolumn{4}{|c|}{$\begin{array}{c}\lambda \\
\text { Consistency Index (CI) } \\
\text { Consistency Ratio (CR) }\end{array}$} & $\begin{array}{l}3.0103 \\
3.0387 \\
0.0194 \\
0.0334\end{array}$ \\
\hline
\end{tabular}

A multi-criteria evaluation (MCE) matrix, as shown in Table 4, and the prototype of the CRF-new map (in Figure 5) are the results of the implementation of the CFR-new equation (Equation (11)).

Table 4. Matrix of the MCE for the CFR-new.

\begin{tabular}{|c|c|c|c|c|c|c|c|}
\hline \multirow{2}{*}{ Parameter } & \multirow{2}{*}{ Weighting } & \multicolumn{6}{|c|}{ Classification of the Coastal Flood-prone Area } \\
\hline & & High & Score & Moderate & Score & Low & Score \\
\hline $\begin{array}{c}\text { Land } \\
\text { cover/use }\end{array}$ & 1.20 & Settlements & 3 & $\begin{array}{c}\text { Bushes/ } \\
\text { agriculture/ } \\
\text { mixed } \\
\text { crops/ } \\
\text { plantations }\end{array}$ & 2 & $\begin{array}{c}\text { Rice } \\
\text { fields/forest/ } \\
\text { gardens/ } \\
\text { sand/bare } \\
\text { land }\end{array}$ & 1 \\
\hline Slope & 0.20 & $0-2 \%$ & 3 & $2-4 \%$ & 2 & $4 \%$ & 1 \\
\hline Rainfall & 0.03 & $\geq 200 \mathrm{~mm}$ & 3 & $\begin{array}{c}\text { 50-200 } \\
\mathrm{mm}\end{array}$ & 2 & $\leq 50 \mathrm{~mm}$ & 1 \\
\hline
\end{tabular}

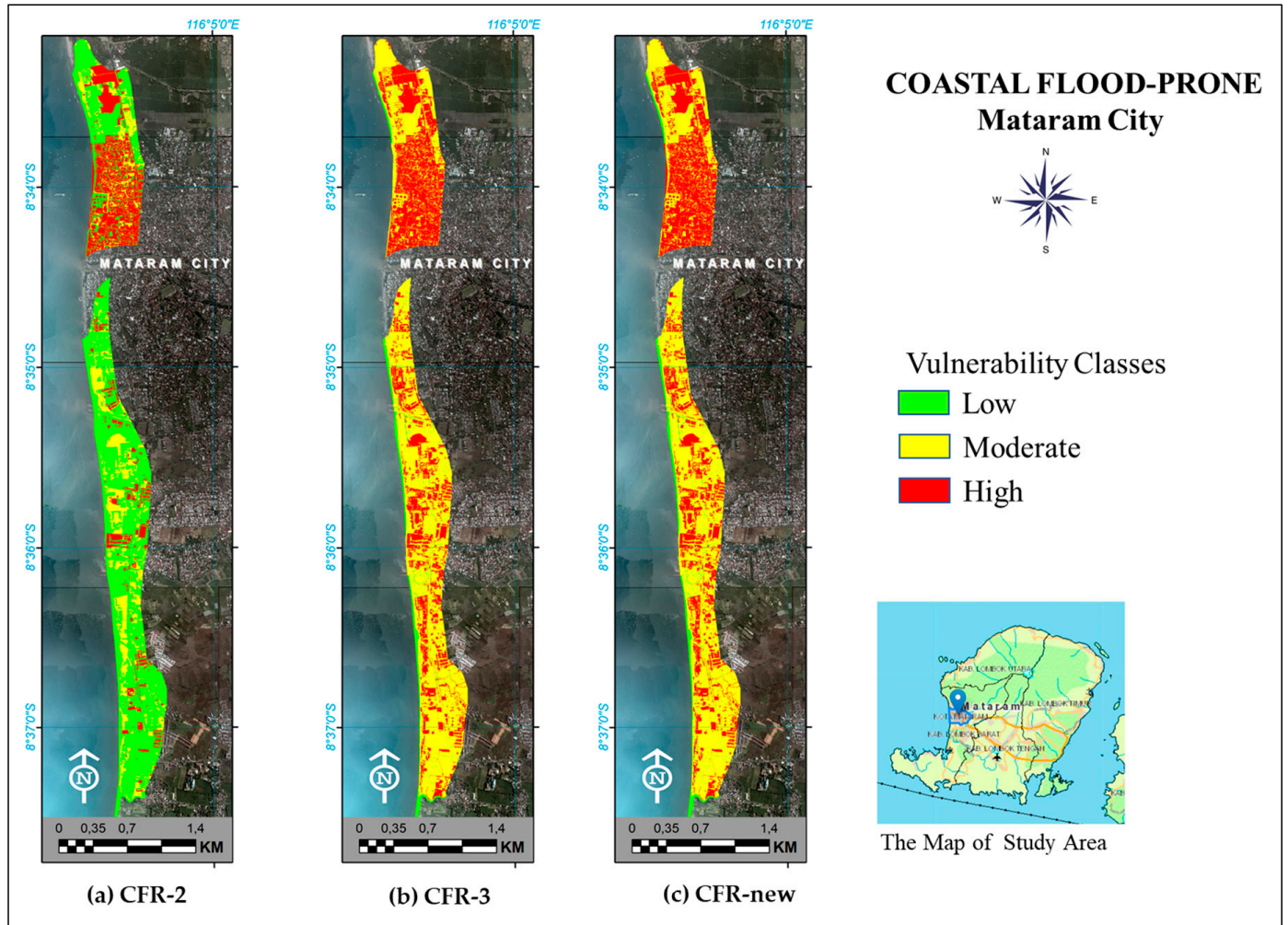

Figure 5. CFR mapping based on CFR-2 (a), CFR-3 (b), and CFR-new(c). 
The new equation for CFR-new can be defined as follows:

$$
F_{i}=1.20 s_{l i} p_{l}+0.20 s_{s i} p_{s}+0.03 s_{r i} p_{r}
$$

where $F_{i}$ is the flood-prone area of class $i, s_{l i}$ is the scoring for parameter $p_{l}=$ land use at class $i, s_{s i}$ is the scoring for parameter $p_{s}=$ slope at class $i$, and $s_{r i}$ is the scoring for parameter $p_{r}=$ rainfall at class $i$.

The findings show slight differences between the CFR-3 and the CFR-new map. The coverage of the high-vulnerability class in the CFR-new was 2.56 ha larger than the CFR-3. Conversely, the moderate-vulnerability class was 179.98 ha and 182.54 ha, respectively (Figure 5 and Table 5).

Table 5. Flood-prone area of CFR-2, CFR-3, and CFR-new.

\begin{tabular}{cccc}
\hline \multirow{2}{*}{ Prone Classes } & \multicolumn{3}{c}{ Area (ha) } \\
\cline { 2 - 4 } & CFR-2 & CFR-3 & CFR-New \\
\hline High & 58.65 & 101.28 & 103.84 \\
Moderate & 56.98 & 182.54 & 179.98 \\
Low & 183.09 & 14.90 & 14.90 \\
\hline
\end{tabular}

It can be said that the application of the CFR-new method was more accountable compared to the CFR-2 and CFR-3 methods, because it was applied to the measured and proven weight values of each parameter's criterion. Thus, it was essential to measure the weight before conducting the spatial analysis processes.

\subsection{Coastal Flood-Prone Area Method Based on Combined Drivers}

Following the use of AHP to develop the CFR-new, a judgement matrix was constructed for the CFC, as shown in Table 6, which summarizes the normalized weights. The matrix ( $\lambda$ max $=4.01185$; $\mathrm{CI}=0.0395 ; \mathrm{RI}=0.90 ; \mathrm{CR}=0.0439<0.1)$ meets the $\mathrm{CR}$ acceptable criteria described by Saaty $[39,40]$.

Table 6. AHP judgement matrix of the coastal flood-prone areas by combined drivers (CFC)-affecting parameters and consistency ratio assessment.

\begin{tabular}{|c|c|c|c|c|c|c|c|c|c|c|}
\hline & Slope & $\begin{array}{l}\text { Tidal } \\
\text { Wave } \\
\text { Inundation }\end{array}$ & $\begin{array}{c}\text { Land } \\
\text { Cover/Use }\end{array}$ & Rainfall & $\sum_{\text {Rows }}^{\sum}$ & $\begin{array}{l}\text { Eigen } \\
\text { Vector }\end{array}$ & Result & Weight & $\begin{array}{l}\text { Weighted } \\
\text { Sum } \\
\text { Vector } \\
\text { (WSV) }\end{array}$ & $\begin{array}{l}\text { Consistency } \\
\text { Vector (CV) }\end{array}$ \\
\hline $\begin{array}{l}\text { Slope } \\
\text { tidal }\end{array}$ & 1 & 3 & 5 & 7 & 2.23 & 0.5579 & 1.2441 & 1.24 & 2.3556 & 4.2223 \\
\hline $\begin{array}{l}\text { wave } \\
\text { inundation }\end{array}$ & 0.33 & 1 & 3 & 5 & 1.05 & 0.2633 & 0.2765 & 0.28 & 1.0995 & 4.1757 \\
\hline $\begin{array}{l}\text { Land } \\
\text { cover/use }\end{array}$ & 0.20 & 0.33 & 1 & 3 & 0.49 & 0.1219 & 0.0597 & 0.06 & 0.4919 & 4.0357 \\
\hline Rainfall & 0.14 & 0.2 & 0.33 & 1 & 0.23 & 0.0569 & 0.0131 & 0.01 & $\begin{array}{c}0.2299 \\
\lambda\end{array}$ & $\begin{array}{l}4.0403 \\
4.1185\end{array}$ \\
\hline & & & & \multirow{2}{*}{\multicolumn{6}{|c|}{$\begin{array}{l}\text { Consistency Index (CI) } \\
\text { Consistency Ratio (CR) }\end{array}$}} & 0.0395 \\
\hline & & & & & & & & & & 0.0439 \\
\hline
\end{tabular}

Then, the CFC equation was developed as follows:

$$
F_{i}=1.24 s_{s i} p_{s}+0.28 s_{w i} p_{w}+0.06 s_{l i} p_{l}+0.01 s_{r i} p_{r}
$$

where $F_{i}$ is the flood-prone area of class $i, s_{l i}$ is the scoring for parameter $p_{l}=$ land use at class $i, s_{s i}$ is the scoring for parameter $p_{s}=$ slope at class $i, s_{w i}$ is the scoring for parameter $p_{w}=$ tidal wave at class $i$, and $s_{r i}$ is the scoring for parameter $p_{r}=$ rainfall at class $i$.

The average tidal wave height $\left(h_{c}\right)$ on Lombok island is 1.00 to $1.25 \mathrm{~m}$, with the extreme tidal waves reaching $>2 \mathrm{~m}$. By considering the extreme and average heights, the terrestrial inundation $\left(x_{r}\right)$ 
caused by the tidal wave ranged from $14.93 \mathrm{~m}$ to $>47.68 \mathrm{~m}$. An MCE matrix, as shown in Table 7, and the prototype of the CFC mapping (in Figure 6) was developed based on the CFC equation (Equation (12)).

Table 7. Matrix of the MCE for the CFC method.

\begin{tabular}{|c|c|c|c|c|c|c|c|}
\hline \multirow{2}{*}{ Parameter } & \multirow{2}{*}{ Weighting } & \multicolumn{6}{|c|}{ Classification of the Coastal Flood-Prone Area } \\
\hline & & High & Score & Moderate & Score & Low & Score \\
\hline Slope & 1.24 & $0-2 \%$ & 3 & $>2-4 \%$ & 2 & $>4 \%$ & 1 \\
\hline $\begin{array}{l}\text { Tidal wave } \\
\text { inundation }\end{array}$ & 0.28 & $\leq 14.93 \mathrm{~m}$ & 3 & $\begin{array}{c}>14.93-47.68 \\
\mathrm{~m}\end{array}$ & 2 & $>47.68 \mathrm{~m}$ & 1 \\
\hline $\begin{array}{c}\text { Land } \\
\text { cover/use }\end{array}$ & 0.06 & Settlements & 3 & $\begin{array}{l}\text { Bushes/ } \\
\text { agriculture/ } \\
\text { mixed } \\
\text { crops/ } \\
\text { plantations }\end{array}$ & 2 & $\begin{array}{l}\text { Rice fields/ } \\
\text { forest/ } \\
\text { gardens/ } \\
\text { sand/bare } \\
\text { land }\end{array}$ & 1 \\
\hline Rainfall & 0.01 & $\geq 200 \mathrm{~mm}$ & 3 & $\begin{array}{c}\text { 50-200 } \\
\text { mm }\end{array}$ & 2 & $\leq 50 \mathrm{~mm}$ & 1 \\
\hline
\end{tabular}

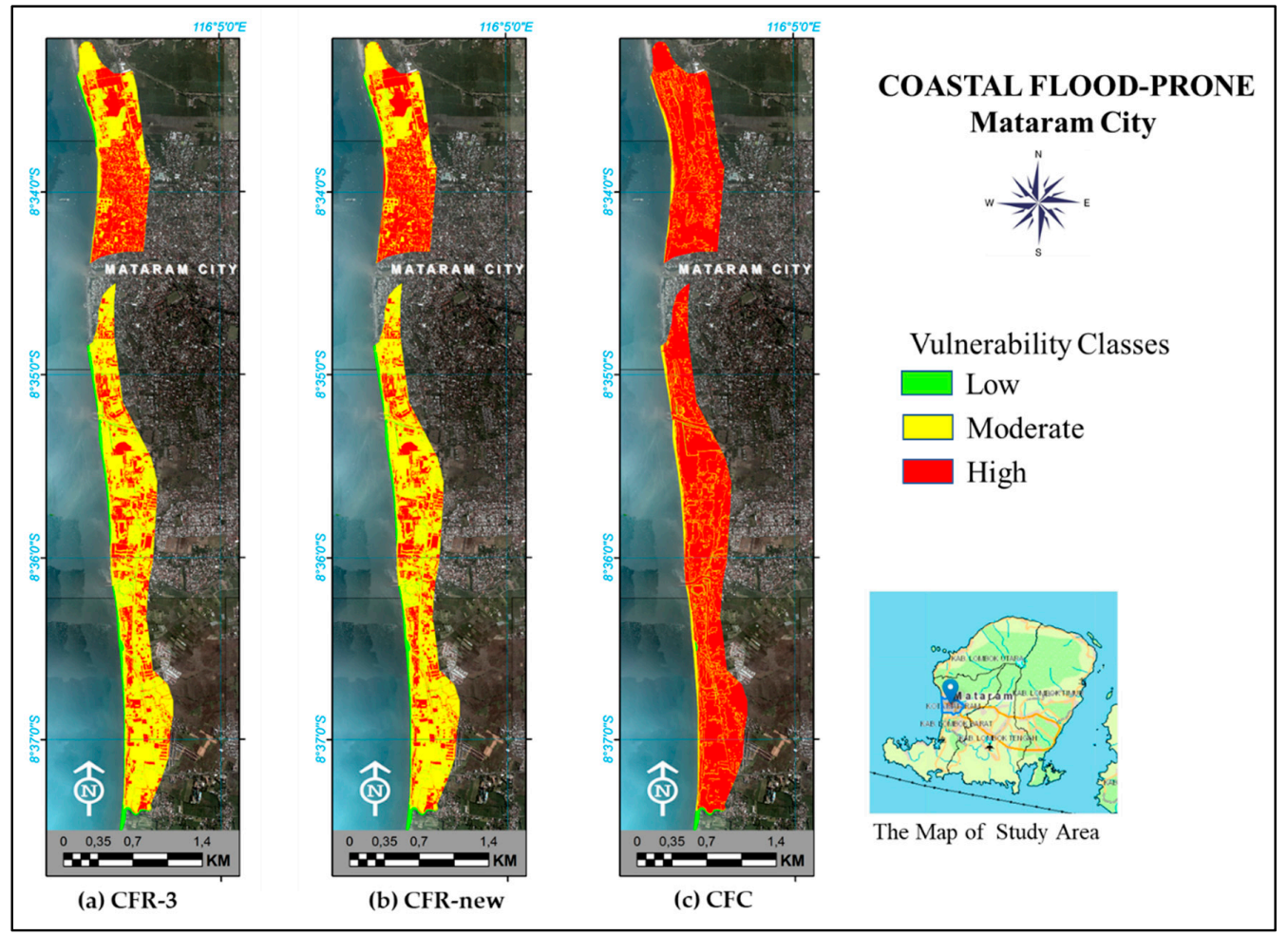

Figure 6. The flood-prone mapping based on CFR-3 (a), CFR-new (b), and (c) coastal flood-prone areas by combined drivers (CFC).

The findings show considerable differences when compared to the CFR, because the implementation of the CFC method classified almost all of the area as vulnerable (Figure 6). Table 8 shows the differences in the extents of the three models based on the MCE analysis, which significantly expanded the inshore boundary in the CFC model implementation by as much as 244.02 ha for the high-vulnerable class. 
Table 8. Flood-prone area analyses from the (a) CFR-3 parameters, (b) CFR-new (c), and CFC combined drivers.

\begin{tabular}{cccc}
\hline \multirow{2}{*}{ Prone Classes } & \multicolumn{3}{c}{ Area (ha) } \\
\cline { 2 - 4 } & CFR-3 & CFR-New & CFC \\
\hline High & 101.28 & 103.84 & 244.01 \\
Moderate & 182.54 & 179.98 & 48.94 \\
Low & 14.9 & 14.9 & 5.76 \\
\hline
\end{tabular}

\section{Discussion}

The methodology established in this study highlights the minimum parameters needed for coastal flood-prone area mapping and the role of AHP for developing an equation that is necessary to specify the vulnerability classes. It shows that climate and land characteristic parameters are important for determining flood-prone area mapping. Several researchers [41-43] agree that land characteristics (such as land cover, topography/slope, and geomorphology) and climate (such as rainfall and extreme tidal waves) are influential in determining the occurrence of floods. The findings show how the integration of these parameters can determine the worst impact of the extent of inundation across coastal alluvial plains (Figure 6 and Table 7). The explanation of the added parameters and the methods are as follows:

a. Land cover is essential for the CFR and CFC methods: [30] shows the empirical link of flooding to land use and land cover conversion that plays a vital role in the occurrence of flooding. Table 5 showed the increase of high and moderate vulnerability classes when the land cover/use parameter was added, with 42.63 ha for the high class and 125.56 ha for the moderate class from CR-2 to CR-3, respectively.

b. The CFC method allows more detailed impacts on the land: [44,45] supports that coastal and deltaic areas are susceptible to flooding from the combined effects of excess rainfall and astronomic tide inundations. Table 8 describes the differences in susceptibility of the moderate and low classes in CFR-3 and CFR-new, with 142.74 ha and 140.18 ha, respectively, to CFC while an extreme tidal wave was added to the model.

c. Flooding depends on geomorphological units: [46] supports the importance of hydro-geomorphological aspects for coastal flood mapping in that an alluvial plain can be used to delineate flood hazard areas based on his research in Constantine City, Algeria. The geomorphological type of the Mataram City coast is an alluvial plain. As can be seen in Figure 6, using either the CFR or CFC method, the alluvial plain area in the study site is vulnerable to flooding and can be used as a mapping unit. The observation area indicates that the highest tidal wave caused a dynamic form of the alluvial plain, which sometimes created a sand embankment along the coast of Mataram City. This condition may intensify the inundation of the area, especially in low areas that are blocked by sand embankments. In his research in Vietnam, [47] indicated that flooding and the dynamic mechanism of alluvial formation were correlated and, in turn, affected the flooding hazard.

Another important finding is the role of expert judgment through AHP to develop an equation for coastal flood-prone mapping. Generated thematic maps by using an overlay analysis can be based on the weighted scores of each factor in the AHP model [48]. Ref. [49] supports the importance of weighting values as a central step in the multi-criteria analysis process. AHP assists in decision-making by organizing quantitative and qualitative data in an integrated, transparent, and structured way [50]. Based on the weights and scores derived using AHP, coastal flooding vulnerability maps can be assessed as low, medium, and high-vulnerability classes (Figures 5 and 6). Therefore, it is essential to measure the weight before conducting spatial analysis processes.

Other issues that should be evaluated is the selection of the drivers of the flooding despite the land characteristic issues and rainfall. Our research selected the tidal wave as the ocean driver, because 
tidal flood events have been increasing recently in Indonesia [10]. The northern coast of Java Island has been the worst affected by this phenomenon [10]. The implementation of a combined method has also been done by many researchers worldwide. For example, several researchers assessed storm tides and heavy rainfalls as a combined driver in their studies, sequentially, [51] for Crookhaven Head and Shoalhaven Head Estuaries, NSW, Australia, [52] North Folk, VA, USA, and [53] for Saint Louis in the Caribbean Sea. However, the method they used was the hydrological model without any level of flood vulnerability classes. An AHP application for flooding and its vulnerability class research was employed by [35] on the Coast of Lithuania in the South-Eastern Baltic Sea. However, his research did not apply the combined drivers but only the micro-tidal wave drivers. Therefore, the combined drivers supported by the AHP method for the development of the equation-based weighted scored method has become important to enrich the coastal flood-prone area mapping technique.

\section{Evaluation of the CFR-new and CFC methods}

The development of the equations for both methods, CFR-new and CFC, were found consistent by using CR analysis. The extent of the accuracy of the prototype with the ground conditions was evaluated by using the logical test method to compare the findings with the field data as a reference. The reference data represents actual flood events occurring in the alluvial plain area. Without distinguishing flood classes, about $97 \%$ of the alluvial area is vulnerable to flooding, utilizing either CFR-new $=96.25 \%$ or $\mathrm{CFC}=97.5 \%$. However, in considering the classification of vulnerability, the results of the evaluation were dissimilar; there was $51.25 \%$ conformity obtained for CFR-new and $98.75 \%$ for CFC (Figure 7).

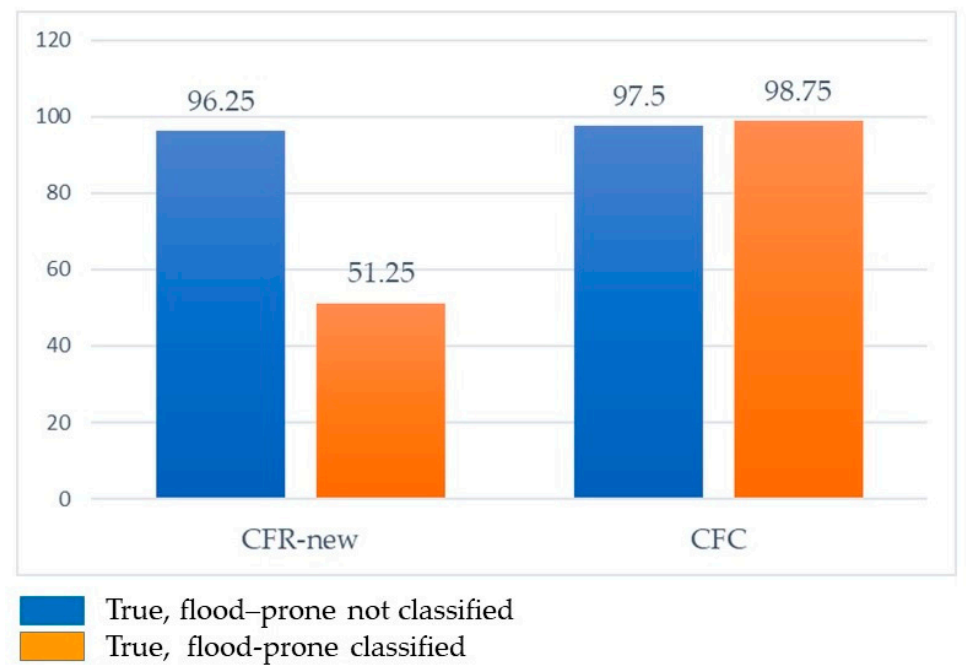

Figure 7. Evaluation of the CFR-new vs. CFC combined drivers in the classified and not-classified flood-prone categories.

Ref. [20] concluded that river discharge was largely responsible for flooding along the river and the river mouth. The [18] study supports that a tidal wave would cause higher flooding along the river mouth of the Ampenan and the Sekarbela subdistricts. Thus, it can be said that the CFR-new value was lower because the high-vulnerability classes of the CFC had a strong relationship with the river mouth. Both CFR and CFC found high vulnerability classes around the Jangkik River in the Ampenan subdistrict and the Unus and Berenyok Rivers in the Sekarbela subdistrict.

\section{Conclusions}

Some studies have assessed coastal flooding using tide and rainfall data independently. However, within coastal areas, flooding cannot be caused solely by a single factor. Ref. [52] reported that heavy rainfall, alongside the storm tide, exacerbated the severity of coastal flooding. Indeed, [54] supported that rainfall and tidal waves contribute to coastal inundation. The combination of rainfall, tidal wave, 
geomorphology, and other land characteristic factors are correlated as the causes of coastal flooding. This study proposed a method and prototype of CFC using the coastal area of Mataram City, Lombok, Indonesia as an example. The findings showed that the combined model increased the identification of flood-prone areas compared to the single-driver model. The minimum parameters for determining the flood-prone areas can be identified from this study; there is the slope, land cover/use, rainfall, and tidal waves. The findings also indicate the need for expert judgment for the development of equations that involve multi-criteria analysis and so does the assumption of using an alluvial plain as the unit for mapping. Therefore, this study may become a useful input for the existing national standard, which only considers rainfall as the affecting factor for flooding. Thus, the equation derived from the AHP analysis for the mapping technique based on the weighted-score method should also be considered to update the national standard.

Besides that, there are still other factors affecting flooding phenomenon that may enrich the scientific realm in the field of coastal flooding. Tidal waves are not the only factor that can cause coastal flooding. Sea levels rising, storm surges, and other high waves are additional drivers that should be studied due to their impacts on coastal inundation. The characteristics of the drivers are also regionally dependable. Therefore, it is likely that the study of multiple drivers for coastal flooding can be further developed.

Author Contributions: Dewayany Sutrisno and Ati Rahadiati were the main contributors of this article, and both contributed to the conceptualization, methodology, analysis, validation, writing the draft, and article preparation, while Aninda W. Rudiastuti, Ratna Sari Dewi, and Munawaroh were the other contributing members. Aninda W. Rudiastuti contributed to the tidal wave data analysis and field data analysis, Ratna Sari Dewi contributed to the field data analysis, and Munawaroh contributed to the rainfall data analysis. All authors have read and agreed to the published version of the manuscript.

Funding: This research was funded by the Geospatial Information Agency, State Budget No 083.01.01.3539.967.001.052.C: The Research on Coastal Vulnerability Mapping.

Acknowledgments: This work was supported by the Geospatial Information Agency of the Republic of Indonesia, West Nusa Tenggara Province Regional Government, and Mataram City Regional Disaster Management Office. We also would like to express our gratitude to the anonymous reviewers for their comments and suggestions to this article.

Conflicts of Interest: The authors declare no conflict of interest.

\section{References}

1. Wolf, J. Coastal flooding: Impacts of coupled wave-surge-tide models. Nat. Hazards 2008, 49, 241-260. [CrossRef]

2. Lewis, M.J.; Palmer, T.; Hashemi, R.; Robins, P.; Saulter, A.; Brown, J.; Lewis, H.; Neill, S. Wave-tide Interaction Modulates Nearshore Wave Height. Ocean Dyn. 2019, 69, 367-384. [CrossRef]

3. Zai, V.R.C. Arahan Dan Rekomendasi Pemanfaatan Lahan Untuk Kawasan Permukiman Wilayah Pesisir Kelurahan Tanjung Mas Dan Kelurahan Bandarharjo (Directions and Recommendatins of Utilization to a Residential Coastal Area in Tanjung Mas and Bandarharjo District). In Proceedings of the Seminar Nasional Geomatika 2018, Bogor, Indonesia, 5 September 2018. [CrossRef]

4. Ramsay, D.B.; Bell, R. Coastal Hazards and Climate Change. A Guidance Manual for Local Government in New Zealand, 2nd ed.; Ministry for the Environment: Wellington, New Zealand, 2008.

5. Purbani, D.; Salim, H.L.; Kusuma, L.P.A.S.C.; Tussadiah, A.; Subandriyo, J. Ancaman gelombang ekstrim dan abrasi pada penggunaan lahan di pesisir Kepulauan Karimunjawa (Studi kasus: Pulau Kemujan, Pulau Karimunjawa, Pulau Menjangan Besar dan Pulau Menjangan Kecil)/The extreme waves and abrasion hazards on coastal land use at Karimunjawa Islands (Case Study: Kemujan Island, Karimunjawa Island, Menjangan Besar Island and Menjangan Kecil Island). J. Kelaut. Nas. 2019, 14, 33-45.

6. Center for Disease Control and Public Health. Coastal Flooding, Climate Change, and Your Health What You Can Do to Prepare; US Departement of Health and Human Services, Center for Disease Control and Prevention: Atlanta, GA, USA, 2017. 
7. Handayani, W.; Fisher, M.R.; Rudiarto, I.; Setyono, J.S.; Foley, D. Operationalizing resilience: A content analysis of flood disaster planning in two coastal cities in Central Java, Indonesia. Int. J. Disaster Risk Reduct. 2019, 35, 1-12. [CrossRef]

8. Nugraha, A.L.; Santoso, B.P.; Aditya, T. Dissemination of tidal Flood Risk Map using Online Map in Semarang. Proceedings ICTCRED (International Conference on Tropical and Coastal Region Eco-Development) 2015. Proc. Environ. Sci. 2015, 23, 64-71. [CrossRef]

9. Griggs, G.; Davar, L.; Reguero, B.G. Documenting a century of coastline change along Central California and associated challenges: From the qualitative to the quantitative. Water 2019, 11, 2648. [CrossRef]

10. Nirwansyah, A.W.; Boris, B. Mapping impact of tidal flooding on solar salt farming in Northern Java using a hydrodynamic model. ISPRS Int. J. Geo Inf. 2019, 8, 451. [CrossRef]

11. Hamdani, H.; Perman, S.; Susetyaningsih, A. Analisa daerah rawan banjir menggunakan aplikasi sistem informasi geografis (Studi kasus Pulau Bangka). J. Konstr. Sekol. Tinggi Teknol. Garut 2014, 12, 1-13.

12. Badan Standarisasi Nasional. SNI 8197:2015 Metode Pemetaan Rawan Banjir sekala 1:50,000 dan 1:25,000; Badan Standarisasi Nasional: Jakarta, Indonesia, 2015.

13. Roy, S.L.; Pedreros, R.; André, C.; Paris, F.; Lecacheux, S.; Marche, F.; Vinchon, C. Coastal flooding of urban areas by overtopping: Dynamic modelling application to The Johanna Storm (2008) in Gâvres (France). Nat. Hazards Earth Syst. Sci. 2015, 15, 2497-2510. [CrossRef]

14. Badan Nasional Penanggulangan Bencana (Ed.) Peraturan Kepala Badan Nasional Penanggulangan Bencana No. 2/2012 Tentang Pedoman Umum Pengkajian Risiko Bencana, Dengan Parameter Tinggi Gelombang, Arus, Tutupan Vegetasi, Bentuk Garis Pantai Dan Tipologi Pantai, Difokuskan Di Daerah Sempadan Pantai; Badan Nasional Penanggulangan Bencana: Jakarta, Indonesia, 2012.

15. Olbert, A.I.; Comer, J.; Nash, S.; Harnett, M. High-resolution multi-scale modelling of coastal flooding due to tides, storm surges and rivers inflows. A Cork City example. Coast. Eng. 2017, 121, 278-296. [CrossRef]

16. Purba, M.; Utami, I.N. Karakter dan pergerakan masa air di Selat Lombok bulan Januari 2004 dan Juni 2006 (Characteristics and circulation of water mass at Lombok Strait in January 2004 and June 2006). J. Ilmu Ilmu Perair. Perikan. Indones. 2006, 13, 143-153.

17. Bappeda Provinsi Nusa Tenggara Barat. Kajian Resiko Bencana Kota Mataram (The Assessment of Disaster Risk in Mataram City); Bappeda Provinsi Nusa Tenggara Barat: Mataram, Indonesia, 2019.

18. Rahmanto, M.R.; Susetyo, C. Pemodelan spasial genangan banjir akibat gelombang pasang di wilayah pesisir Kota Mataram. J. Tek. ITS 2017, 7, 2337-3520. [CrossRef]

19. Suara NTB. Warga Pesisir Pantai di Mataram Butuh Pemecah Gelombang. SuaraNTB.com, 30 July 2018.

20. Sulistiyono, H.; Pradjoko, E.; Syamsidik. Effect of Climate Change Variables on The Coastal Wind Prediction. In Proceedings of the 21st IAHR-APD Congress, Yogyakarta, Indonesia, 2-5 September 2018; Departement of Civil and Environmental Engineering, Gadjahmada University: Yogjakarta, Indonesia, 2018; pp. 549-558.

21. Warsilah, H.; Nadila, S.M. Inclusive Urban Coastal Development in Ampenan and Jerowaru, West Nusa Tenggara. In Proceedings of the 2nd International Conference on Strategic and Global Studies (ICSGS), Central Jakarta, Indonesia, 24-26 October 2018. [CrossRef]

22. Peta NKRI. Peta Pulau Lombok. Available online: https://tanahair.indonesia.go.id/portal-web/download/ perwilayah (accessed on 11 August 2020).

23. World Map. Available online: http://sahimiqm.blogspot.com/2017/01/peta-dunia-kosong.html (accessed on 13 August 2020).

24. Helderop, E.; Grubesic, T.H. Social, geomorphic, and climatic factors driving U.S. coastal city vulnerability to storm surge flooding. Ocean Coast. Manag. 2019, 181,1-11. [CrossRef]

25. Manfreda, S.; Nardi, F.; Samela, C.; Grimaldi, S.; Taramasso, A.C.; Roth, G.; Sole, A. Investigation on the use of geomorphic approaches for the delineation of flood prone areas. J. Hydrol. 2014, 517, 863-876. [CrossRef]

26. Samela, C.; Troy, T.J.; Manfreda, S. Geomorphic classifiers for flood-prone areas delineation for data-scarce environments. Adv. Water Resour. 2017, 102, 13-28. [CrossRef]

27. Berndtsson, R.; Becker, P.; Persson, A.; Aspegren, H.; Haghighatafshar, S.; Jönsson, K.; Larsson, R.; Mobini, S.; Mottaghi, M.; Nilsson, J.; et al. Drivers of changing urban flood risk: A framework for action. J. Environ. Manag. 2019, 240, 47-57. [CrossRef]

28. Lin, W.B.; Sun, Y.M.; Nijhuis, S.; Wang, Z. Scenario-based flood risk assessment for urbanizing deltas using future land-use simulation (FLUS): Guangzhou Metropolitan Area as a ccase study. Sci. Total Environ. 2020, 739, 1-10. [CrossRef] 
29. Canters, F.; Vanderhaegen, S.; Khan, A.Z.; Engelen, G.; Uljee, I. Land-use simulation as a supporting tool for flood risk assessment and coastal safety planning: The case of The Belgian Coast. Ocean Coast. Manag. 2014, 101, 102-113. [CrossRef]

30. Avashia, V.; Garg, A. Implications of land use transitions and climate change on local flooding in urban areas: An assessment of 42 Indian cities. Land Use Policy 2020, 95, 1-9. [CrossRef]

31. Sushanti, I.R.; Imansyah, N.H. Kajian perubahan fisik spasial kawasan urban fringe di Kecamatan Ampenan Kota Mataram. J. Planoearth 2018, 3, 44-48. [CrossRef]

32. Lathrop, R.; Lisa, A.; James, T.; Bognar, J. The Application of webgis tools for visualizing coastal flooding vulnerability and planning for resiliency: The New Jersey Experience. ISPRS Int. J. Geo Inf. 2014, 3, 408-429. [CrossRef]

33. Xu, Y.; Lu, Y. Adaptive weighted fusion: A novel fusion approach for image classification. Neurocomputing 2015, 168, 566-574. [CrossRef]

34. Tercan, E.; Dereli, M.A. Development of a land suitability model for citrus cultivation using GIS And multi-criteria assessment techniques in Antalya Province of Turkey. Ecol. Indic. 2020, 117, 1-11. [CrossRef]

35. Bagdanaviciute, I.; Kelpsaite, L.; Soomere, T. Multi-criteria evaluation approach to coastal vulnerability index development in micro-tidal low-lying areas. Ocean Coast. Manag. 2015, 104, 24-135. [CrossRef]

36. Kudláč, Š.; Majercak, J.; Štefancová, V. Using the Saaty Method and the FMEA Method for Evaluation of Constraints in Logistics Chain. Procedia Eng. 2019, 187. [CrossRef]

37. Liu, F.; Zou, S.C.; Li, Q. Deriving priorities from pairwise comparison matrices with a novel consistency index. Appl. Math. Comput. 2020, 364, 1-15. [CrossRef]

38. Sutrisno, D.; Windiastuti, R.; Oktaviani, N.; Rudiastuti, A.W. A feasibility study of seabed cover classification standard in generating related geospatial data. Geo Spat. Inf. Sci. 2019, 22, 304-313. [CrossRef]

39. Chu, P.; Liu, J.K.H. Note on consistency ratio. Math. Comput. Model. 2002, 35, 1077-1081. [CrossRef]

40. Liu, F.; Zhang, J.W.; Zhang, W.G.; Pedrycz, W. Decision making with a sequential modeling of pairwise comparison process. Knowl. Based Syst. 2020, 1-46. [CrossRef]

41. Haryani, N.S. Analisis Zona Potensi Rawan Banjir Menggunakan Data Penginderaan Jauh dan SIG di Kalimantan Timur. In Proceedings of the Seminar Nasional Penginderaan Jauh ke-4 Tahun 2017, Jakarta, Indonesia, 17 October 2017; LAPAN: Depok, Indonesia, 2017.

42. Rosyiedie, A. Banjir: Fakta dan dampaknya serta pengaruh dari perubahan lahan. J. Perenc. Wil. Dan Kota 2013, 24, 241-249.

43. Wismarini, T.D.; Syukur, M. Penentuan tingkat kerentanan banjir secara geospasial. J. Teknol. Inf. Din. 2018, 20,57-76.

44. Xie, D.; Zou, Q.P.; Mignone, A.; MacRae, J.D. Coastal flooding from wave overtopping and sea level rise adaptation in the Northeastern USA. Coast. Eng. 2019, 150, 39-58. [CrossRef]

45. Bilskie, M.V.; Hagen, S.C. Defining flood zone transitions in low- gradient coastal regions. Geophys. Res. Lett. 2018, 45, 2761-2770. [CrossRef]

46. Bourenanea, H.; Bouhadada, Y.; Guettouche, M.S. Flood hazard mapping in urban area using the hydro-geomorphological approach: Case study of the Boumerzoug and Rhumel Alluvial Plains (Constantine City, NE Algeria). J. Afr. Earth Sci. 2019, 160, 1-8. [CrossRef]

47. Ho, L.T.K.; Umitsu, M. Micro-landform classification and flood hazard assessment of The Thu Bon Alluvial Plain, Central Vietnam via an integrated method utilizing remotely sensed data. Appl. Geogr. 2011, 31, 1082-1093. [CrossRef]

48. He, H.; Di, H.; Qun, S.; Lei, Z.; Yanrong, L.A. A landslide susceptibility assessment method based on GIS technology and an AHP-weighted information content method: A case study of Southern Anhui, China. ISPRS Int. J. Geo Inf. 2019, 8, 266. [CrossRef]

49. Drobne, S.; Lisac, A. Multi-attribute decision analysis in GIS: Weighted linear combination and ordered weighted averaging. Informatica 2009, 33, 459-475.

50. Sekovski, I.; Del Rio, L.; Armaroli, C. Development of a coastal vulnerability index using analytical hierarchy process and application to Ravenna Province (Italy). Ocean Coast. Manag. 2019, 1-11. [CrossRef]

51. Kumbier, K.; Carvalho, R.C.; Vafeidis, A.T.; Woodroffe, C.D. IInvestigating compound flooding in an estuary using hydrodynamic modelling: A case study from The Shoalhaven River, Australia. Aust. Nat. Hazards Earth Syst. Sci. 2018, 18, 463-477. [CrossRef] 
52. Shen, Y.; Morsy, M.M.; Huxley, C.; Tahvildari, N.; Goodall, J.L. Flood risk assessment and increased resilience for coastal urban watersheds under the combined impact of storm tide and heavy rainfall. J. Hydrol. 2019, 1-46. [CrossRef]

53. Zhang, Y. An Integrated Framework to Assess Compound Flood Risks for Interdependent Critical Infrastructure in A Coastal Environment. Master's Thesis, Graduate Program in Civil and Environmental Engineering, The University of Western, London, ON, Canada, 2019.

54. Lee, S.; Kang, T.; Sun, D.; Park, J.J. Enhancing an analysis method of compound flooding in coastal areas by linking flow simulation models of coasts and watershed. Sustainability 2020, 12, 6527. [CrossRef]

(C) 2020 by the authors. Licensee MDPI, Basel, Switzerland. This article is an open access article distributed under the terms and conditions of the Creative Commons Attribution (CC BY) license (http://creativecommons.org/licenses/by/4.0/). 